\title{
Pitfalls and perspectives in cancer genomes NGS studies: implications for predictive, preventive and personalized medicine (PPPM)
}

\author{
Ugo Rovigatti
}

From EPMA-World Congress 2013

Brussels, Belgium. 20-21 September 2013

Great increase in Whole Genome Sequencing (WGS) and Next Generation Sequencing (here: NGS-CA) approaches were witnessed in the past few years, since cataloging or landscaping all possible cancer aberrations appears to be both scientifically relevant and useful for therapeutic strategies. This search has been performed through Medline using NGS with appropriate cancer types/subtypes definitions and paying particular attention to the major overviews from groups on both sides of the Atlantic (i.e., Michael Stratton and Bert Vogelstein: [1] and [2]). Although the most utilized instruments-technologies so far are the 454 pyrosequencing apparatuses and the Illumina platform, technology is continuously developing, such as the Ion-Torrent machines (see below). The scope here is to overview general pitfalls and perspectives in the whole area of NGS-CA studies and to suggest probable trends and prudent recommendations.

\section{Pitfalls}

1. Much fewer reports are present today for pediatric tumors and particularly leukemia/lymphoma in comparison to adult cases (ratio 1:10 / 1:20). This is scientifically counterproductive, as major breakthroughs in our understanding of human cancer often originated from pediatric cancer (also next point). No WGS-NGS studies have been published so far on neuroblastoma or other pediatric tumors [3].

2. It is apparent that many mutations appeared before the time of malignant transformation in an age/dependent fashion. Although the "mutator phenotype" [1][2] is still discussed, this already suggests that some "drivers" may be irrelevant for malignancy onset. Further discrepancies

\footnotetext{
Correspondence: profrovigatti@gmail.com
} Pisa University- Medical School, Pisa, Italy

\section{Perspectives and Recommendations}

1. Further studies should be performed on pediatric cancer, where age is clearly less important/determining factor and where important breakthroughs could be feasible also in the area of UP-CAN ([4],[5]).

2. Technology should be followed with great attention. Introduction of the equivalent of the $P C$ for sequencing - i.e., Ion Torrent - could lead to desperately - needed new discoveries.

3. Gene-targeting approaches failures, accepted as "fait accompli", are rebutted by stating that multiple agents should be effective. Although big pharma's do not test combined agents, this approach should be obviously encouraged.

4. As per Pitfalls and especially in view of the great heterogeneity (intratumoral, intrametastatic, intermetastatic 
and between patients [1][2]) demonstrated in human cancers, additional approaches beside the CAN-GEN and namely the CAN-EPI, CAN-CHROM and particularly UP-CAN should be also pursued [4][5] .

Published: 11 February 2014

\section{References}

1. Stratton MR: Exploring the Genomes of Cancer Cells: Progress and Promise. Science 2011, 331(6024):1553-1558.

2. Vogelstein B, Papadopoulos N, Velculescu VE, Zhou S, Diaz AR Jr, Kinzler KW: Cancer Genome Landscapes. Science 2013, 339(6127):1546-1558.

3. Deyell RJ, Attiyeh EF: Advances in the understanding of constitutional and somatic genomic alterations in neuroblastoma. Cancer Genetics 2011, 204(3):113-121.

4. Rovigatti U: Is there an Infectious Agent behind Prostate Cancer? In Prostate Cancer- InTech Gerhard Hamilton 2013, 46.

5. Kostic AD, Ojesina AL, Pedamallu CS, Jung J, Verhaak RG, Getz G, Meyerson M: PathSeq: software to identify or discover microbes by deep sequencing of human tissue. Nature Biotechnology 2011, 29(5):393-396.

doi:10.1186/1878-5085-5-S1-A30

Cite this article as: Rovigatti: Pitfalls and perspectives in cancer genomes NGS studies: implications for predictive, preventive and personalized medicine (PPPM). EPMA Journal 2014 5(Suppl 1):A30.

Submit your next manuscript to BioMed Central and take full advantage of:

- Convenient online submission

- Thorough peer review

- No space constraints or color figure charges

- Immediate publication on acceptance

- Inclusion in PubMed, CAS, Scopus and Google Scholar

- Research which is freely available for redistribution

Submit your manuscript at www.biomedcentral.com/submit 